\title{
The Exploration of Innovation of Ideological and Political Education Work for Students in Higher Vocational Colleges
}

\author{
Chong Liu \\ Liaoning Vocational College of Economics, ,Liaoning, Shenyang, 110122
}

Keywords: Higher; Vocational;Colleges;Students;Ideological-and political education; Exploration of innovation

\begin{abstract}
The development and changes of the higher vocational education bring not only opportunities to the ideological and political education of students at higher vocational colleges, but also challenges. At this stage, it is particularly important to strengthen innovative construction of ideological and political education for students at higher vocational colleges. Combined with many years of practical experience, the author of this paper first deeply studies the current development of ideological and political education for students at higher vocational colleges, based on which the main problems are analyzed. Finally, innovative plans and proposals are put forward.

Higher vocational education is an important part of China's higher vocational education. It is different from the general undergraduate's emphasis on discipline education. Vocational education is based on occupation classification, guided by talent needs, and based on the needs of professional positions (Group), to cultivate skilled applied talents. Because of this characteristic of higher vocational education, it is the characteristics of the ideological and political education for the higher vocational students. In order to promote the innovation and development of ideological and political education for higher vocational students in the new era, we should base on the present situation and continue to analyze and study in depth.
\end{abstract}

\section{Present situation of ideological and political education for students in higher vocational colleges.}

The macro level includes social factors and the characteristics of development of higher vocational education.

Firstly, social factors bring opportunities and challenges. Higher vocational education in China is in the transition period of social development, and economic globalization has brought people's thinking of diversification, and vocational college students at this stage are also living at the turn of the century era. They are affected by changes in the influence of social environment, whose world outlook and outlook on life and values are impacted. Some students manifest their personalities. They want to take self centred, have cognitive bias, and consider more about reality and economic interests. Therefore, the development of society brings opportunities to the ideological and political education for students in higher vocational colleges, and it also faces great challenges.

Secondly, the characteristics of the development of higher vocational education. The main task of higher vocational education is to deliver skilled talents with high quality to the society. The teaching of higher vocational colleges has always adhered to the training goal of this talent. While accepting the study of theoretical knowledge, higher vocational college students should strengthen their knowledge of professional skills, and pay more attention to the training of students' hands-on operation ability. Therefore, ideological and political education in higher vocational colleges should adhere to pertinence and give full play to their own unique educational advantages. At present, the ideological and political education work for vocational college students is closely related to employment, so as to create employment markets for graduates.

Microcosmic factors include the object of education and the reform of development.

First, the object of higher vocational education. The main object of higher vocational education is college students born after 1995, and students at this age are enjoying rich material resources. They have strong adaptability to new things or ideas. But they are faced with the popularization of the college entrance examination, and the structure of their students is rather complicated. Some 
students are single enrollment and lack self-discipline and self-consciousness. They tend to be self-centered and are less concerned about others' feelings. In addition, higher vocational students are in the era of rapid development of information network, and they are easily influenced by network information and pursue individualization. Or they are confused by the information of the network and it is hard for them to tell the truth. In a word, the development of higher vocational college students is special, which also determines the particularity of the development of ideological and political education at higher vocational colleges.

Second, the development of higher vocational colleges is at the period of reform. In the specific setting of teaching contents, attention should be paid to the development characteristics of higher vocational college students, and theories should be combined with practice. Judging from the current development, the ideological and political education is mainly based on theoretical education. Modern teaching equipment is used with practical operation as auxiliary courses to stimulate students' enthusiasm and initiative in learning. The teaching at higher vocational colleges is mainly composed of two parts: in-class teaching and after-class teaching. Among them, ideological and political teachers are responsible for in-class teaching while after-class teaching is mainly undertaken by related instructors or the related psychological teachers.

\section{Problems in the development of ideological and political education for students in higher vocational colleges.}

The social environment affects the values of the students. The development and changes of the socialist market economy have a direct impact on people's ideological and political ideas or values. Influenced by some unhealthy trends, the students in higher vocational colleges will develop some wrong ideas, money worship, individualism, hedonism and so on. They lack the collectivism of social needs, collate interests and state ideas, etc. All these will impede the balanced development of the ideological and political education for the students in higher vocational colleges.

The multiple contradictions and psychological problems of the students in higher vocational colleges. Students in higher vocational colleges persue freedom and independence. Because escaping from the constraints of the college entrance examination finally, they get overall relaxation of body and mind and are against the shackles of school discipline to a certain extent, and have the rebellious psychology of adolescence. At the same time, because their academic results are not good and they are not good at learning they will have a relatively abased psychology compared with the undergraduate students. In addition, in the face of the confusion of future career selection, it is easy for them to be dazed. They hope not only to be accepted but also it is especially easy for them to go to the extremes of thought.

Impact of emerging network information. With the development and change of the information age, the situation of education development is gradually from closed to open, broadening the students' learning vision and ways. However, it is noteworthy that vocational college students are generally weak in ideology and vulnerable to the interference and influence of negative news. It is difficult for them to judge the authenticity and authenticity of information online and can not distinguish their authenticity accurately. The drawbacks of the emerging network information affect and impede the educational development of students.

The management mode of ideological and political education in higher vocational colleges needs to be explored. Higher vocational college students' sense of initiative learning is weak. Their learning goals and development momentum are not very clear and lack learning motivation and the stability of individual quality. These problems influence their initiative to accept ideological and political education and unwilling to accept all aspects of school management, which reduces the effectiveness of ideological and political education in higher vocational colleges 


\section{Suggestions on strengthening the creative development of ideological and political education for students in higher vocational colleges.}

\section{Protruding the function of culture and educating people and promoting cultural accomplishment.}

With the transformation and development of society, the comprehensive development competitiveness of students in higher vocational colleges is increasing year by year. For their ideological and political education work, we should emphasize cultural education and humanistic care and aim at improving students' comprehensive quality.

Because of the particularity of higher vocational education, more emphasis is placed on students' acquisition of professional skills, and there are deficiencies in the cultivation of cultural literacy. Thus, it can be seen that cultural education should be strengthened in ideological and political education at higher vocational colleges with Xi Jinping's socialist thoughts with Chinese characteristics in the new era as the main guiding ideology to constantly strengthen education of traditional Chinese culture, enrich the teaching contents for higher vocational college students and strengthen the care for students' minds.

Due to the bias and lack of emphasis on students' cognition in higher vocational colleges, the students in higher vocational colleges are restricted in the development of employment. Therefore, in the work of education, the most prominent problem is the enhancement of student anxiety and the confusion of the emotional or work problems. In terms of the management of ideological and political education for students, we should strengthen humanistic care, encourage students, and reduce the need for compulsory development, so that students can form a sense of belonging on campus. For teachers, the construction of their own affinity should be formed and the students' service will be integrated into the daily education and life. At the same time, the communication between teachers and students can be strengthened, and the students' self-awareness and understanding can be further obtained through effective communication methods. Through strengthening the humanistic and innovative development of ideological and political education, the development of higher vocational education can be increased.

\section{Innovating the idea of work to form a joint effort of education.}

Firs of all, establish the people-oriented ideological and political work development concept. Doing well in ideological and political education for students requires teachers to not only be responsible for students' daily life, but also make a long-term plan for their future development and improve the educational ideas to promote the all-round development of students. In term of specific education, try to avoid the phenomenon of emphasizing on labor division while neglecting cooperation, and it is necessary to strengthen the daily educational management of higher vocational college students. It is worth noting that due to the individua differences between students, targeted teaching should be carried out. Only in this way can teachers fully discover students' personal advantages during growth and strive to strengthen the ideological and political education of students.

Secondly, we should strengthen and improve the concept of multi-party coordination and common management. In the ideological and political education, due to the difference of specific duties and positions, we need to excavate the educational function of specialized courses in teaching, so that students can focus on professional quality training while learning professionally. We should give full play to the functions of education in different positions such as management, funding and services. Only when the full participation of staff and the combination of management and education can we really establish a good atmosphere to promote the development of schools. It is difficult for the ideological and political education of the students to achieve the true purpose of education if it is based on the division of labor and the right of each person.

Finally, follow the times to form the concept of active development. With the continuous and deep development of higher vocational colleges, the ideological and political education for higher vocational students should also keep pace with the times. At present, the ideological and political education for higher vocational students has some problems such as the poor quality of educational activities and the lack of educational effectiveness. There are a series of problems in the 
management and education system such as the old methods and the lack of innovative research on ideological and political education, which cannot keep pace with the main theme of the times and will make ideological and political work go into a misunderstanding of circular development. Therefore, we should follow the main trend of the development of the times, turn the passive of the development into the initiative and promote the orderly conduct of ideological and political education in higher vocational colleges.

\section{Give full play to the new advantages of the network platform.}

In ideological and political education at higher vocational colleges, the teaching carrier can be fully combined with to give play to the advantage of teaching carriers. This is mainly because higher vocational college students' ideological and moral character is formed by objective education and students' self-cognition. Among them, objective education refers to using positive and objective educational factors in the development so as to strengthen ideological and political education and promote the all-round development of students. For the education at higher vocational colleges, the main purpose is to cultivate all-round talents with comprehensive skills and strengthen the innovative development of educational carriers.

With the change and development of information age, the campus of higher vocational colleges has become a home place for many cultures to gather and develop. In the process of continuous development, it is easy to appear different voices and enhancing the innovative development of carriers can reduce the impact of negative ideology, promote the development of the times and strengthen the leading and developing effectiveness of mainstream knowledge. Higher vocational colleges can make full use of the development of various types of network information media resources such as campus networks, guiding the ideological and political education for students and using special online discussions and psychological counseling and other forms and continuing to promote the network development of the work of ideological and political education.

\section{Integration of theory and practice in ideological education.}

In the setting of the content of ideological and political teaching in higher vocational colleges, the characteristics of personality tendency can be combined with the main personality psychological characteristics of the students in higher vocational colleges such as common interests, hobbies and temperament,etc.,combined with students' self-consciousness and other distinctive characteristics, stimulate students' inherent potential and constantly develop their quality characteristics.

Firstly, the content of ideological and political curriculum should be set up to strengthen the innovative design, thus enhancing the attraction of Ideological and political class in higher vocational colleges. In the ideological and political class in higher vocational colleges, the related educational activities can be used to assist the teaching based on the classroom teaching as the main form. On this basis, we should pay more attention to the further innovation of teaching methods and means, fully combine teaching materials and students' own thinking and practice, improve the overall teaching effect and achieve the real purpose of classroom teaching.

Secondly, the development of future career vision is strengthened by highlighting the skills advantage. In the course of ideological and political education for higher vocational students, the development advantages of the majors and disciplines should be strengthened and the career vision of future development should be built. We can carry out school enterprise cooperation, take advantage of resources and regional development advantages, take internship or business visit and other educational forms, so that higher vocational students believe in the bright vision of development and constantly enhance their self learning motivation. In addition, faced with the hot problems in the society, educators should carry out the objective teaching in ideological and political education, so as to reduce students' confusion and make students firmly believe in the ideals and beliefs of educational development.

With the development of higher vocational education, the students in higher vocational colleges have become the main force of employment development and actively participate in the social construction. The ideological and political education should be strengthened in the process of higher vocational students' training because of the outstanding application skills of higher vocational students and the lack of humanistic education. We should pay attention to the cognitive bias of 
education in the education for higher vocational college students in the current stage of the development and innovation and ideological and political education work and constantly improve the ideological and political and cultural quality of vocational college students, and promote the healthy development of higher vocational ideological and political education and realize the task of higher vocational education of "moral education" and cultivating socialist qualified successors.

\section{References}

[1] Jian, Y, 2016. The characteristics and education of the students in Higher Vocational Colleges. Cooperative economy and science and technology. (21).

[2] Rongshneg,X, et al 2013. New media and ideological and political education in Universities. University (Academic Edition) (5): 57.

[3] Daoguang,C,2015. Study on the particularity and Countermeasures of the ideological and political education of the students in higher vocational colleges in the new period. (10).

[4] Wei,M,2014. Research on the carrier innovation of Ideological and political education in higher vocational colleges under the new media environment. Journal of Shenzhen Polytechnic. 13 (4): 79-82.

[5] Li,S, 2015.On the ideological and political work of students in higher vocational colleges. (18).

[6] The CPC Central Committee and the State Council 2014. Opinions on Further Strengthening and improving the ideological and political education of College Students.

[7] Guorong,C.2016. The scientific development concept leads the innovation of college students' ideological and political work. Journal of Huazhong Agricultural University. (5).

[8] Ping,C,2013.On strengthening ideological and political education and building harmonious campus of colleges and universities. Journal of Xiangtan Normal College (SOCIAL SCIENCE EDITION). (03)

[9] Yibin,Z,2016.The close combination of ideological party building with the system of building the party, promoting the construction of the party in Universities. China Higher Education. (23).

[10]Zhidan,Z,2016. The exploration and reflection of education of higher vocational college ideological and political science are carried out by using university-enterprise cooperation. South Wind. (20). 